\title{
THE NEEDS AND READINESS ANALYSIS OF SOCIAL AUDIT IMPLEMENTATION IN INDONESIA
}

\author{
Budi Santoso ${ }^{1}$ \\ Fakultas Ekonomi \\ Universitas Muhammadiyah Jember \\ budisantoso@unmuhjember.ac.id
}

\author{
Bayu Aprillianto ${ }^{2}$ \\ Fakultas Ekonomi \\ Universitas Muhammadiyah Jember \\ mr.aprillianto@gmail.com
}

\begin{abstract}
ABSTRAK
Penelitian ini bertujuan untuk menganalisa pentingnya audit sosial di Indonesia melalui studi literatur. Hasil riset mengindikasikan : 1) Indonesia sangat membutuhkan audit sosial untuk menjelaskan dan proses kontrol isu laporan CSR di perusahaan supaya kredibel dan konsisten. 2) Beberapa negara telah menjalankan audit sosial dan Indonesia bisa mengadopsi audit tersebut, namun disesuaikan dengan kondisi riil program audit yang ada di Indonesia. Kontribusi dari riset ini munculnya kesadaran para stakeholder lebih tinggi terhadap evaluasi dan monitoring pelaksanaan CSR melalui audit sosial, karena audit sosial sangat diperlukan bagi kita, pemerintah pada umumnya dan perusahaan secara khusus. Kemudian kita harus concern terhadap audit sosial ini.
\end{abstract}

Kata Kunci : $\quad$ Pelaksanan dan Pelaporan CSR; Sosial Audit

\begin{abstract}
This study aimed to analyze the needs of Indonesia to implement social audit using literatures study methodology. The result shows that: 1) Indonesia highly needs social audit to check and verify the credibility and reliablity the CRS report issued by the company, 2) Some countries have already implement social audit and Indonesia can adopt their implementation, certainly with the local circumstances of Indonesia which support this social audit concern. This study was expected to increase awareness of all stakeholders to more concern toward the evaluation and monitoring on CSR implementation through social audit, because social audit is very useful for us, government, companies, and the universe rather. Thus, we should pay attention to this social audit.
\end{abstract}

Keywords : $\quad$ CSR implementationEreport; social audit

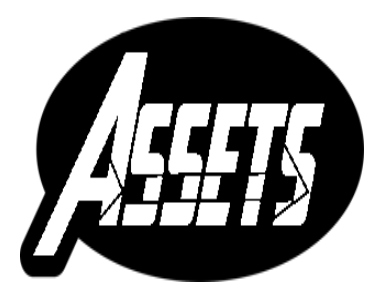

ASSETS

Jurnal Akuntansi dan Pendidikan

Vol. 8 No. 1

Hlmn. 35 - 46

Madiun, April 2019 p-ISSN: 2302-6251

e-ISSN: 2477-4995

Artikel masuk: 07 November 2018 Tanggal diterima: 30 April 2019 


\section{INTRODUCTION}

Corporate Social Responsibility (CSR) is a series of corporate responsibility that should be conducted in addition to the main business operation of a company. Lawrence and Weber (2017); Koldovskyi (2015) defined CSR as an activity of corporates to conduct their responsible in three aspects called as triple bottom line, namely economic, social, and environment concerns. Those companies have to integrate their activities into their values, culture, decision making, strategy, and operations in the context of transparency and accountability (International Professional Practice Framework-IPPF, 2010). Thus, those companies can establish better corporate practices in creating wealth and improve society by considering the economic, social, and environment.

Ethical thinking directs the companies should give their contribution to their surrounding in the form of CSR, nevertheless the practice has not really been implemented. Hence, it appears the pressure from the other parties to implement CSR namely from stakeholders. Freeman (2008) stated that

"... The key idea about capitalism is that an entrepreneur or manager creates value by capturing the jointness of the interests (of the stakeholders).Yes, sometimes the interests are in conflict, but the over time they must be shaped in the same direction. "

Stakeholders theory stated by Freeman (2008) explained that stakeholders give pressure to the companies to adopt CSR namely governments, investors, political groups, customers, communities, employees, trade associations, suppliers, and government, so that the companies attempt to meet the needs of those stakeholders (based on Freeman's stakeholder models). CSR began to be implemented by the companies and many people started to pay attention to CSR since 1960's. Thus, it made the CSR evolving until today (Maignan, 2002: Rahim and Vicario, 2015). The companies also make a CSR report and used by the stakeholders. Hence, CSR has information content and also used in the decision making of investors (Chen et al., 2015).

The problem appeared later related to the use of information content of CSR reporting by investors while there has been no independent assessment yet related to CSR reports provided by the companies. Credibility of transparency and accountability became a problem, because of the skepticism about the content of the report. Narcissism can indeed happen in CSR reporting of company, since there has been no independent assessment of CSR report (Sakina, 2014). Narcissism in this case related to efforts to exaggerate or even manipulate the CSR report of a company in an effort to attract investors. That is because the presence of CSR is expected to increase the company's reputation through the creation of good corporate image on society (Chen, 2015; Porter and Kramer, 2006).

This social audit has been growth in some countries. Developed country like U.S., United Kingdom, some commonwealth countries, India and Australia, also Nepal and Bangladesh have implemented social audit (Casey and Grenier, 2014; ACORAB,2013; Ahmed; 2012). Looking at the list of the countries implemented social audit, Indonesia also has a possibility to take a part in this social audit concern. Indonesia has implemented CSR, its companies also report their CSR activities. Based on the explanation above, thus this study aimed to analyze the need and readiness of social audit to be implemented in Indonesia.

\section{RESEARCH METHOD}

This study is qualitative study using literature study approach to capture and analyze of phenomenon of social audit implementation in some countries around the 
world and certainly Indonesia. The experience of those countries in social audit used to explain the needs and to analyze the readiness of Indonesia to implement social audit.

\section{RESULT AND DISCUSSION}

\section{The Needs of Social Audit Implementation in Indonesia}

The First and Main Need of Social Audit Implementation in Indonesia: A History and The Become Essential

CSR has existed and developed for more than 50 years ago since 1960's (Maignan, 2002; Rahim and Vicario, 2015). CSR has also been campaigned and implemented in the universe, because of the crucial need of CSR to maintain the human's life. In principle, CSR refers to the concept of triple bottom line i.e people, planet, and profit. Accordingly, the company has to contribute to the environment in that three aspects.

Indonesia had required the implementation of CSR in mining companies based on issued regulation number 40 article 74 year of 2007 for limited company. This regulation applied since August, 16th 2017, consisting of 4 points which are: 1) Limited companies operating their business in/or related to natural resources is mandatory implementing social and enviroment responsibility, 2) Social and environment responsibility in point (1) is an obligation of companies which is budgeted and calculated as companies cost, the implementation has to notice the comliance and fairness, 3)The limited companies who don't implement this obligation in point (1) are going to get punishment based on local government regulation, 4) The further provision regarding this social and environment responsibilty is regulated by local government regulation.

Based on that regulation, it mandates that companies operates business in natural resources (mining companies) to implement CSR. Along with time, CSR implementation followed by non-mining companies. Actually, the Indonesian companies had been implementing CSR since a long time ago, eventhough they didn't name that activity as CSR (Suharto, 2008). And now, companies listed in Indonesia Stock Exchange voluntarily issued CSR or sustainability reporting annually. It indicates that the Indonesian companies especially limited companies responded the market demand of transparancy and accountabilty not only in financial aspect, but also non financial aspect, namely CSR.

The company highly needs to perform more accountable, more transparant, and more responsibile entity indeed. Thus, the company needs to report its social performance through CSR or sustainability report. The purpose of reporting is as a form of accountability to the stakeholders because however stakeholders have interest to CSR activities of companies, even some also make pressures on companies to adopt CSR as a result of stakeholder theory and agency theory (Cooper and Owen, 2007; Donaldson and Preston, 1995).

There are 2 base of this CSR report namely voluntary and mandatory base (Maignan, 2002; Rahim and Vicario, 2015). Both base liberate the company to issue its CSR report into the standalone report (sustainability report) or incorporated in annual report. There has been no regulation requiring this term. The CSR reports in Indonesia have been using Global Reporting Initiative Guideline (GRI Guideline) for their CSR or sustainabilty reporting. GRI Guideline is an voluntary standard of sustainability reporting using triple bottom line basis i.e people, planet, and profit (GRI, 2013). Thus, the Indonesian CSR report orientated on those 3 aspects and also general information regarding the company. 
The issued-CSR reports were actually responded by the market, it was caused by the information content of the CSR report, and market responded (Anderson and Frankle, 1980; Rown-Liburd and Zamora, 2014; Chen et al, 2015; Sayekti and Wondabio, 2007). This can be figured in this Throughput Governance Corporate Model:

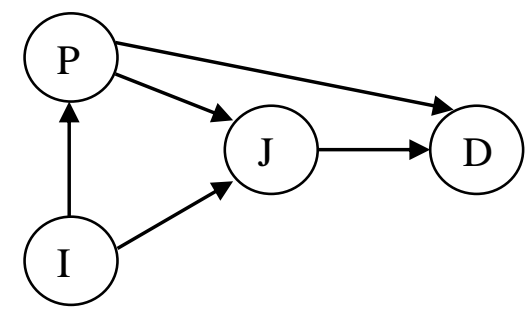

Figure 1. Throughput Governance Corporate Model

Source: Rodgers et al, 2007

Where:

$\mathrm{P}=$ Perception of CSR (costumers, employees, communities, environments, etc.) and the opinion of auditor (clean report vs warning signals).

$\mathrm{I}=$ Financial and non financial informations.

$\mathrm{J}=$ Judgement (financial viability).

$\mathrm{D}=$ Decision choice (valuation of common stock).

Through that model, it can be analyzed that the perception of CSR by stakeholder affects the judgement on financial viability and also affects the decision choice.

The current CSR or sutainability report especially in Indonesia is a description of company's program and activity in CSR, mostly in words. The lack is in the possibility to interpret the words. We will conclude different from two sentences that basically have the same content. In Indonesia, CSR or sustainability report is only a story of company in implementing CSR. If talking about the story, a reality will mean different through various way to deliver the story.

A sentence of "contributing to the society by fostering the weaving craftsmen" will have various interpretation with a sentence of "contributing to the society by conducting the training and accompaniment to the weaving craftsmen". It depends on the hermeneutics. The second sentence has an opportunity to get more positive interpretation rather than the first sentence, because the second sentence has the word of "accompniment" as complement which means more caring of the weaving craftsmen. On the other side, philosophically both sentences are probably different. Presumably, the first sentence shows a real activity of company committing CSR through its intensive fostering to the weaving craftsmen, otherwise the second sentence is just an accompaniment in short period, not an intensive accompaniment. There are various interpretation of the sentence affecting the received-information content. This various information content is feared will mislead the investors and other user of CSR or sustainabulity report. Do not let the CSR or sustainability report ending to become just a misleading rhetoric. Let's see! Related to fulfilling the user's interest, we sought to be care of or not? Through the same words but different meaning. We can't trust those words and compare without a tool to assure the credibilty and reliability the CSR or sustainability report.

CSR report is used by the users but has no adequate credibility. Similarly, financial reports, CSR reports also need to be audited to create credibility. For example, investors also use CSR report of a company as a reference in making investment decisions (Chen et.al, 2015). There was a positive relationship between CSR 
performance on stock performance. Brown-Liburd and Zamora (2014) explained the need of examining CSR report by using the assurance, their study resulted that investor would give higher response of CSR report that had assurance. Thus. it can be analyzed that the existence of CSR reports either in separate or incorporated in the annual report is considerably important to be reported correctly based on the reality.

The discrepancy between the CSR report with the fact of CSR implementation is likely to happen. The assumption is implementation of CSR incorporated the elements of the company's strategy through the translation of the vision and mission of the company in the CSR implementation (Sayekti, 2015; Porter and Kramer, 2006). Then the company tried to increase the image of the company through its CSR implementation. A company might deliberately exaggerate its CSR report with the aim to attract more investors (Sakina, 2014). Legitimacy theory explained this thought where company tries to increase the legitimation of company in society by publishing 'exaggerated'-CSR report, 'exaggerated' in description of CSR activities for the certain motive (Godfrey et al, 2010; Sakina, 2014; Watts and Zimmerman, 1986).

The sama argument came from Kay (2017) in SAN (Social Audit Network) Conference 2017 stated that what is happening now? The need to check, verify, challenge, and endorse what people write about their own organization, for their learning (improve), and for the others (prove), how do we know what is fake news? This ide can be figure in Figure 2 about the skepticism of CSR report.

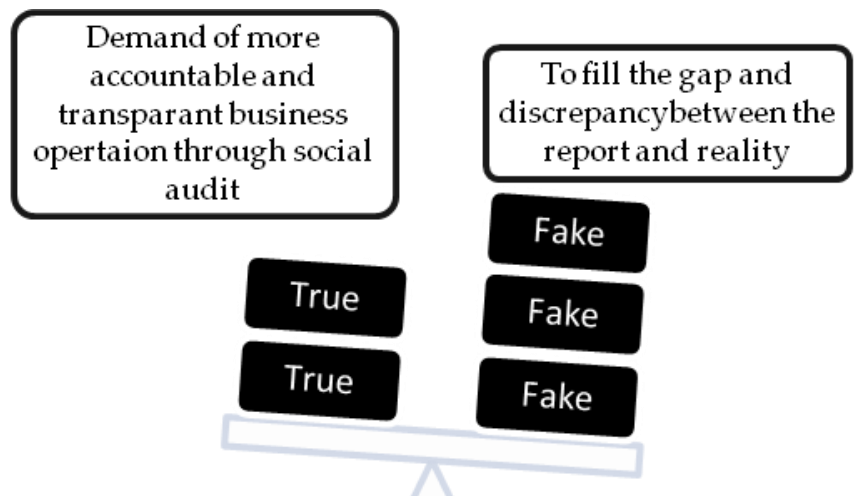

Figure 2. Skepticism of CSR Report

Generally, there are 2 character of company implementing CSR, namely nonstrategic CSR and strategic CSR. Non-strategic CSR explains the company purely implementing CSR without any certain motive, only to fulfill the government regulation or purely as philanthropy program., whereas strategic CSR refers to how company not only implementing CSR but also embedding the company's strategy to maximize profit through CSR program (Porter and Kramer, 2006; Sayekti, 2015). Skepticism appears when company only tries to achieve the goal, to maximize profit by publishing a fake CSR report, or company tries to protect some bad issues through publishing CSR report (King and McDonnel, 2012; Raim and Vicario, 2015).

Eventually, we can conclude that the main reason of social implementation is to create more accountable and transparant business activity, thus able to also create assured and verified infrmation content of CSR (Bello and Mekka, 2015); Brown-Liburd and Zamora, 2014; Du and $\mathrm{Wu}, 2016$ ).

The Indonesian government should carry out a social audit to ensure that the implementation of CSR obligations have been implemented properly and accordingly. Despite, actually a CSR report is already able to meet the responsible of company 
against its CSR activities. Nevertheless, the government should be skeptical of the report. Social audit can fulfill the lack of credibility of the CSR report, thus it can assure the credibility, the reliability, and the transparency of CSR report (Rahim and Vicario, 2015).

The article of GRI in 2013 discussed about the need of external assurance of sustainabilty reporting. External assuarance which conducted by third parties indicates the independent evaluation of annual sustainbality reporting. It aims to build the trust and confidence in the scope of governance, management, and stakeholders relationship.

Based on the exposure, social audit is considerably needed. This is the best thing that can possibly do under these circumstances. Social audit needs to be conducted in order to assess the implementation of CSR undertaken by the company. Although the average implementation and reporting of CSR is on a voluntary basis, but on a mandatory basis is necessary to apply a social audit. If local government establishes the mandatory regulation to conduct social audit, it can be a means to monitor the implementation of CSR.

Eventually, it is understood that the social audit is a concept and method of assessment and monitoring CSR activities undertaken by the company in CSR or sustainability report. Referring to this understanding, can be derived that social audit can also provide benefits for the company in the process of planning, managing, and measuring non-financial activities (CSR) and its impact on external parties (Sofia, 2010).

\section{The Need to Guarding the CSR Implementation Through Social Audit}

The implementation of CSR either strategic or non-strategic has the goal and the purpose that determined by the management earlier. Generally, the goal and the purpose of CSR is how to contribute to the environment through CSR, how the company is able to increase the quality of life through given-CSR. While the spesific goal and purpose depend on the management of the company.

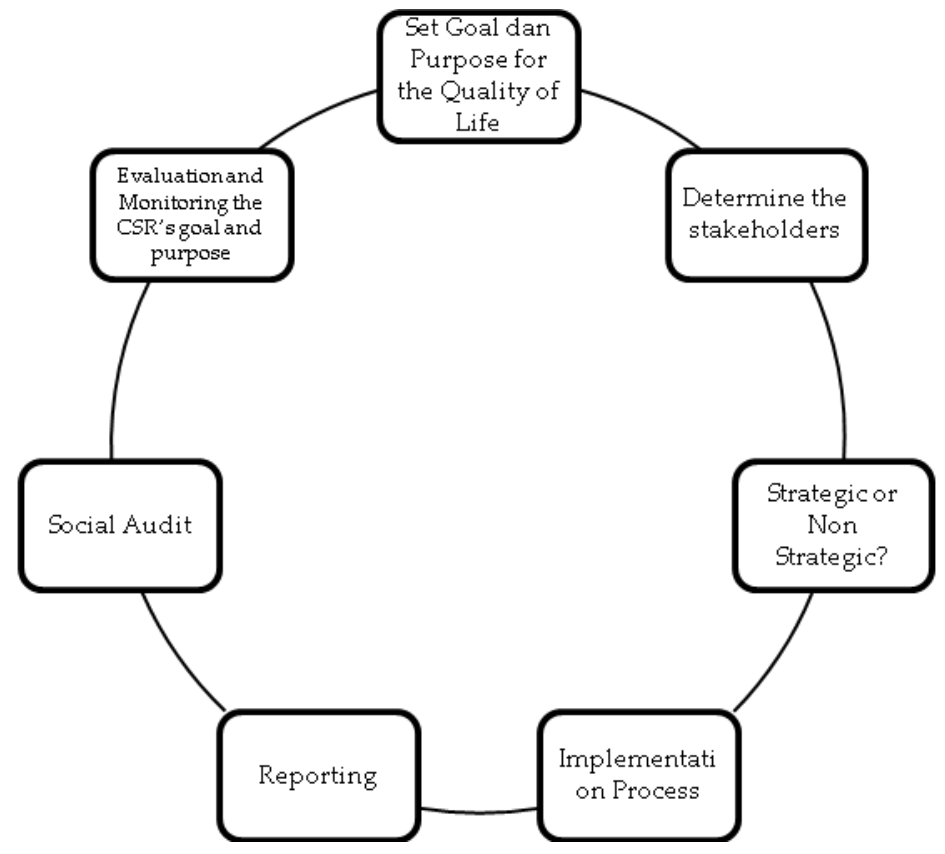

Figure 3. The Need of Evaluation and Monitoring CSR

The company which choose to implement strategic CSR tends to have spesific goal and purpose, because strategic CSR is related to the strategy of company in maximizing profit and to fulfill stakeholder's interest (Sayekti, 2015). The purpose of 
this strategic CSR can be explained by 2 intedependent analysis model by Porter and Kramer (2006) namely inside-out linkages and outside-in linkages. Inside-out linkages refers to the relationship of the impact of company on stakeholders, whereas outsidein linkages refers to the relationship of the impact of environment and stakeholders on company (Porter and Kramer, 2006).

The company should determine the purpose of CSR implementation through 3 ways stated by Porter and Kramer (2006) namely 1) identifying the intersection of the interest of society and company, 2) choosing aimed-social issue, 3) increasing less initiative and generating huge benefit especially for that society and company. Certainly, the porpose should bring the triple bottom line concept.

Social audit can be employed to measure the successfulness of company in achieving the CSR purpose. Other than as a tool of checking and verifying the credibility and reliability of CSR report, social audit also can be employed as a tool for monitoring and evaluation of CSR implementation. Kay (2017) explained that social audit need to clarify the CSR purpose by 1) writing the vision, mission, and objective value of CSR implementation, 2) for impact object, mapping what should be done, the resulted output, and seeing at the outcome and the impact in longer period, 3) for organization object, mapping the value added from social, environment, and economics aspect, also thinking of the key aspect of organization with social and ethical purpose.

Referring to the stakeholder theory that CSR implementation existed as the aftermath of stakeholder interest. Thus, the social audit can be a tool for stakeholders in monitoring and evaluation the CSR implementation. Stakeholders can give their influence to the company with respect to beneficial-social impact that received by the society, accordingly it can be continous improvement on CSR implementation, as stated in outside-in linkages concept by Porter and Kramer (2006). Afterwards, in inside-out linkages (Porter and Kramer, 2006), social auditor can present the social audit report to the management because the social audit report can give the result of monitoring and evaluation of CSR implementation related to the internal aspect of company involving in CSR. For example, any recommedation of efficiency and effectiveness in cost of CSR. It is important to consider the cost being compared with the purpose of CSR. It is to avoid the loss for company caused by CSR implementation.

This social audit is not about the company and society. Furthermore, social audit also contribute to the local government. The Indonesian government had issued the regulation of CSR implementation. The Indonesian government should not stop at this point, the regulation should followed by a scrutiny or monitoring. Social audit can be employed to fulfill this need. The government can use the social audit report to control the CSR implementation by the company.

\section{Readiness Analysis of Social Audit Implementation in Indonesia}

Is Indonesia ready to implement social audit? This is a hard question, but should be answered optimistically. Even though, Indonesia has no social audit institution yet, but in order to realize more accountable and trasnparant business operation, Indonesia should take part in this issue. The question of readiness of Indonesia can be answered by outside-in and inside-out linkage following the concept of Porter and Kramer (2006).

The Needs Based On the Implementation of Social Audit in Some Countries: Being Sophisticated Like The Other Countries

To know the readiness of Indonesia to implement social audit is by finding out the social audit implementation in the world. This reflect the concept of outside-in 
linkages by Porter and Kramer (2006). The implementation of social audit in the world can be an example for Indonesia.

Preston (1997) stated the concept of auditing and CSR report also needed to be audited. Initiated with the emergence of financial statement auditing, then followed by management auditing and program auditing. Last on top, social audit arised as the development of stakeholder demand. This social audit defined as reaction against principle and practice of conventional accounting. The scope of financial and economic perspective are wider, encompassing not only economc and moneter variable, but also sosial aspect that can be quantified

The idea of social audit emerged in 1960s (Lawrence and Weber, 2017). Based on the SAN (Social Audit Network) in UK, the implementation pioneered by Social Audit Limited in 1970's. Social Audit Limited issued social audit report for companies in 1970 's. At that time, the demand of social audit was only for plantation and local community. Afterwards in 1980's, the scope of social audit developed on the impact of company to the environment. The concept still developed until the effort to find and learn about what companies need to do and how companies use their fund to invest, and emerged the role of "watchdog". The consumers also questioned how the consumer's behaviours influence the action of company and government. Eventually, the development of this social audit concept existed to fulfill the stakeholder's interest extensively, where this social audit is able to invovle the role of society to control and influence the company (www.socialauditnetwork.org.uk accessed on May, 2nd 2018).

Social audit grew up until today. U.S., United Kingdom, India, Nepal, Bangladesh, and Australia have implemented social audit (Casey and Grenier, 2014; ACORAB, 2013; Ahmed, 2012). Since the first appearance of social audit in 1970-an, U.K. and Europe described that the social audit concept was to evaluate the CSR activities and the impact on job, community, and environment. Subsequently in 1997, Social Enterprise Partnership developed the program of european social audit. It involved some european countries such as Irland, Spain, Finland, Sweden, Denmark, and England. NICDA (CGG, 2005).

\section{Table 1. Website of Social Audit Network in Some Countries}

\begin{tabular}{lll}
\hline No. & Countries & Website \\
\hline 1. & United Kingdom & www.socialauditnetwork.org.uk \\
2. & India & www.san.india.org. \\
3. & Australia & www.socialaudit.gov.in \\
\hline
\end{tabular}

The purpose of social audit is to create a good accountability of every single social activities in social report. United Kingdom and some commonwealth countries paid more attention to this issue. They made Social Audit Network (SAN). It is a good action to build and support the growth of social audit. Table 1 shows the website of their social audit network respectively. U.K., India, and Australia has lead the growth of social audit. The implementation of CSR in Indonesia will be perfect if Indonesia follows those countries to implement social audit and join in SAN.

Those countries also employ the standards of this issue i.e. AA1000 Assurance Standard, SA8000, and SAE 3000. Those 3 standards are not the standard for social audit but can be a guideline to implement social assurance. Even though, those are an assurance standard, it is still possible to implement as long as the goal is similar which is to verify, evaluate and monitor the CSR activities through assurance service of CSR report. 


\section{The Needs by the Local Circumstance: Is it suitable for Indonesia?}

It is also a hard question for Indonesia. This question can be answered by insideout linkage using concept of Porter and Kramer (2006). Inside-out linkages aims to analyze and consider the capital of Indonesia to implement social audit. Capturing the implementation of CSR in Indonesia, government had established the mandatory regulation to implement CSR for mining companies. Moreover, not only mining companies, but also non-mining companies obeyed the regulation. Sustainability report published by 'go public-companies' indicated the growth of CSR implementation in Indonesia. Many literatures discussed about the CSR issue related to the market, governance, government, and some others. Indonesia also built up CSR into Sharia Social Responsibility (sofia, 2010). The level of CSR growth in Indonesia until combining the concept of CSR with Islamic concept is a good achivement for Indonesia. It means that Indonesia is really care of sustainable development through CSR. This can be considered by Indonesia to implement social audit.

Another consideration coming from NCSR. Indonesia also has an institution dealing with CSR. It is National Center of Sustainability Reporting (NCSR) Indonesia. This institution provides service to train how to make CSR report and how to assure CSR report through GRI Certified Standard Training and Certified Sustainability Reporting Assuror. NCSR employs GRI because mostly companies in Indonesia uses this guideline to make CSR report (sustainability report). In order to encourage the other companies to make CSR report through Indonesia Sustainability Reporting Award (ISRA). Thus, this assurance service given by NCSR Indonesia indicates a good step to initial a social audit in Indonesia (www.ncsr-id.org).

The existence of external assurance implementation of CSR or sustainability report was suggested by Global Reporting Initiative as mentioned in article of GRI (2013). The idea of external assurance in this case is to discuss the same need of independent evaluation of sustainability report. The company tries to builg the trust and confidence of its sustainability report. This idea of external assurance is still voluntary, not required, and GRI doesn't provide this service and the standard of external assurance (GRI, 2013). External assurance also provided by NCSR through the training service namely Certified Sustainability Reporting Assuror (CSRA). NCSR employs AA1000 Assurance Standard as guideline to train the participant of CSRA. The purpose of CSRA is to create graduations that can assure the sustainability report which is made by company (www.ncsr-id.org).

Ultimately, those facts can be analyzed that Indonesia highly need CSR report. The study of Sayekti (2015) also showed that investors of Indonesian company responded CSR report through stock market analysis, because they concluded that CSR performance affected stock price. This empowers the need of social audit in Indonesia in order to show a good CSR report by showing stronger credibility, reliability, and transparency through social audit report. Hence, there would be no investors being misled by CSR report.

This idea of social audit implementation can be realized through the support of government. In order to make a good governance, Indonesian government should arrange a regulation for social audit issue just like CSR implementation. Eventually, Indonesia could pay more attentions to sustainable development.

\section{CONCLUSION}

CSR had experienced significant growth until this decade, not only in worldwide but also in Indonesia. The growth level came to social audit level. This study conclude that: 1) Indonesia highly needs social audit as a means to check and verify the 
credibility and reliabilty of CSR report and to evaluate and monitor the CSR activities through its CSR report. The first possible step is by proposing a basic concept and a conceptual framework to implement social audit from the experience of countries implemented social audit. Even though the concept of social audit has not been widely implemented in many countries, but more important that social auditors will go well if they are supported by the local government through government legal provisions (regulation) to conduct social audit. 2) Indonesia is ready to implement socil audit. This is caused by outside-in linkage analysis which shows that some countries such U.S., U.K., India, and Australia have implemented CSR and social audit. Indonesia has also implemented CSR, and now it it's for Indonesia to adopt their experience of social audit by joining their network which is SAN (Social Audit Network). Afterwards by inside-out linkage analysis shows that how well the growth of CSR in Indonesia. There is an Indonesian private institution which is NCSR (National Center of Sustainability Reporting). It gives more attention to this issue and it provides CSR report preparer and CSR report assuror training.

This study has limitation regarding the elaboration about social audit methods to conduct social audit. We also need to find out more social audit implementation studies from the other countries. Then those can be compared with the circumstances in Indonesia. Finally, future research can propose a basic concept and conceptual framework of social audit implementation in Indonesia.Future social audit should understand the matching concept of social audit to be implemented in Indonesia. Indonesia still needs to build a concept. Even though the concept of social audit has not been widely implemented in many countries, but more important that social auditors will go well if supported by the government through government legal provisions (regulation) to conduct social audits.

Thrugh this article, the result is expected to increase awareness of all stakeholders such as governments, companies, communities and other stakeholders in particular concerning in the verification, evaluation and monitoring the implementation of CSR through social audits, especially for Indonesia. Indonesia has been giving much attention to CSR implementation. Indonesia needs more development of CSR. Social audit can be another way, because this is very useful for us, the government, companies, and the universe rather. Thus, we should pay attention to this social audit concern.

\section{DAFTAR PUSTAKA}

ACORAB. (2013). Public Hearing and Social Audit Implementation Guideline. ACORAB Nepal.

Ahmed, Asif. (2012). Social and Environmental Auditing; Some Basic Concept. Journal of The Institute of Chartered Accountants of Bangladesh.

Bello, Holtjana and Meka, Elvin S. (2015). Auditing of Corporate Social Responsibility (Case Study - Albanian Banking Sector). SSRN Electronic Journal.

Brown-Liburd, Helen L., and Zamora, Valentina L. (2014). The Role of Corporate Social Responsibility (CSR) Assurance in Investors' Judgements When Managerial Pay is Explicity Tied to CSR Performance. Auditing: A Journal of Practice \& Theory, Forthcoming.

Casey, Ryan J. and Grenier, Jonathan H. (2014). Understanding and Contributing to the Enigma of Corporate Social Responsibility (CSR): Assurance in the United States. Auditing: A Journal of Practice \& Theory, Forthcoming. 
Chen, Long, Srinidhi, Bin, Tsang, Albert. dan Yu, Wei. (2015). Audited Financial Reporting ad Voluntary Disclosure of Corporate Social Responsibility (CSR) Reports. Journal of SSRN.

Cooper, S. and Owen, D. (2007). Corporate Social Reporting and Stakeholder Accountability: The Missing Link. Accounting, Organizations and Society, 32, 649-667.

Donaldson, T. and Preston, L.E. (1995). The Stakeholder Theory of the Corporation: Concept, Evidence, and Implcations. Academy of Management Review, 20(n1) (pp. 337-359).

$\mathrm{Du}$, Kai dan $\mathrm{Wu}$, Shing-Jen. (2016). The Credibility of Corporate Social Responsibility Reports and The Role of Assurance: Evidence from Alternative Setting. SSRN Electronic Jounal.

Freeman, R. E. (2008). Ending the so-called 'Friedman-Freeman' debate," in B. R. Agle, T. Donaldson. R. E. Freeman, M. C. Jensen, R. K. Mitchell, and D. J. Wood “Dialogue: Toward superior stakeholer theory. Business Ethics Quarterly, 18(2), 153-190, (pp. 162-166).

Godfrey, Jayne, dkk. (2010). Accounting Theory 7th Edition. Milton: John Willey \& Sons.

GRI. (2013). External Assurance of Sustainability Reporting. Global Reporting Initiative.

Kay, Alan. (2017). Social Audit Gathering of Social Audit Network in 2017.

King, Brayden and McDonnel, Mary-Hunter. (2012). Good Firms, Good Targets: The Relationship between Corporate Social Responsibility, Reputation, and Activist Targeting. Corporate Social Responsibility in a Globalizing World: Toward Effective Global CSR Frameworks. Edited by Kiyoteru Tsuitsui and Alwyn Lim. (Forthcoming). SSRN Electronic Journal.

Koldovskyi, Artem. (2015). Corporate Responsibility Audit: Theoretical Aspects. Risk Governance \& Control: Financial Market \& Institutions. 5(3).

Kurihama, Ryuuichiro. (2007). Role for Auditing in Corporate Social Responsibility and Corporate Governance: Under New Corporate View. Corporate Ownership \& Control. 5(1).

Lawrence, Anne T. and Weber, James. (2017). Business \& Society: Stakeholders, Ethics, Public Policy 15th Edition. New York: McGraw-Hill.

Maignan, Isabelle, dan Ralston, David A. (2002). Corporate Social Responsibility in Europe and the U.S.: Insights from Business' Self-Presentations. Journal of International Business Studies. 33(3), (pp. 497-514).

Peter Rogers, Kazi F. Jalal, John A. Boyd. (2007). An Introduction to Sustainable Development ,ISBN 976-1-84407-520-6.

Porter, M.E., and Kramer, M.R. (2006). Strategic and Society: The Link Between Competitive Advantage and Corporate Social Responsibility. Harvard Business Review, Dec., (pp. 1-15).

Preston, L. E., \& O'bannon, D. P. (1997). The Corporate Social-Financial Performance Relationship. Business And Society, 36(4), (pp. 419-429).

Rahim. Mia M dan Vicario Victor. (2015). Social Audit: A Mess or Means in CSR Assesment). Springer International Publishing Switzerland 2015.

Sakina, Diajeng Ade. (2014). Narsisme Dalam Pelaporan Corporate Social Responsibility: Analisis Semiotik Atas Sustainability Reporting PT. Kaltim Prima Coal dan PT. Perkebunan Nusantara XIII (Persero). E-Jurnal Ekonomi Bisnis dan Akuntansi, (1)1. 
Sayekti, Y. (2015). “Strategic Corporate Social Responsibility (CSR), Company Financial Performance, and Earning Response Coefficient: Empirical Evidence on Indonesian Listed Companies", Procedia - Social and Behavioral Science, 211.

Sayekti, Y., \& Wondabio, L.S. (2007). Pengaruh CSR Disclosure terhadap Earning Response Coefficient: Suatu Studi Empiris Pada Perusahaan yang Terdaftar Di Bursa Efek Jakarta. Simposium Nasional Akuntansi X.

Sofia. (2010). Analysis of the Economic and Social Council on Social Audit Experience and Prospects for Development. Economic and Social Council Publications, Republic of Bulgaria, 34.

Suharto, Edi. (2008). Menggagas Standar Audit Program CSR. In Round Table Discussion AAI 2008. http://wartawarga.gunadarma.ac.id2010/02/menggagasstandar-audit-program-csr/ accesed on June, 2nd 2018.

Watts, Ross L., Zimmerman, Jerold L. (1986). Positive Accounting Theory. New Jersey: Prentice Hall, Inc. 